\title{
ACCESS TO JUSTICE - TRUST AND PERCEPTIONS OF THE ROMA MINORITY
}

\author{
Gabriela PETRE 1 \\ DOI: $10.35782 / J C P P .2021 .2 .03$
}

"This paper was elaborated within the Human Capital Operational Program 2014-2020, co-financed by the European Social Fund, under the project POCU/380/6/13/124708 no. 37141/23.05.2019, with the title "Researcher-Entrepreneur on Labour Market in the Fields of Intelligent Specialization (CERT-ANTREP)", coordinated by the National University of Political Studies and Public Administration.

\begin{abstract}
Discrimination and inequality for various reasons continue to be a reality of everyday life throughout the European Union, as confirmed by the results of surveys and various national studies and research published in recent years. At the level of vulnerable groups (including people in poverty, ethnic minorities, young people, the elderly or women) discrimination and inequality are more pronounced. Access to justice for these disadvantaged groups should contribute to increasing inclusion, increasing socio-economic integration, but barriers (lack of education, information, lack of identity documents, lack of material resources, etc.) in the way of access to justice are sometimes too extended for these people. Thus, the inability of disadvantaged people to access legal services is both a result and a cause of the low degree of inclusion and development, as well as the high degree of vulnerability. This article bighlights the trust and perceptions of Roma minority in Romania in the justice system in the context in which justice is still far from meeting the expectations of citizens, access to justice being unequal especially due to geographical, economic, cultural, social, psychological / temporal barriers. The article makes an important contribution to a broader understanding of the size and nature of the legal needs of members of the Roma minority and the obstacles they face in seeking legal protection in general, but especially for guiding public policies in the field of justice based on reality perceived by those involved in this complex phenomenon.
\end{abstract}

Keywords: Roma minority, justice, social inclusion, poverty, human rights.

\section{Introduction}

In general terms, justice is considered an ideal of responsibility and fairness, which implies that the lack of access to justice for all citizens undermines democratic governance. Thus, access to justice is crucial for both the rule of law and democracy, because an equally accessible justice system for all can produce tangible, individual and just social outcomes (Meçe, 2015).

$1 \mathrm{PhD}$ Student, National School of Political and Administrative Studies. Email: gabrielapetre87@ gmail.com 
Globally, the main problems of access to justice are best expressed by the fact that according to the World Justice Project report (WJP, 2020), 5.1 billion people or about two-thirds of the world's population face at least one issue of justice. Also, to outline the impact of these issues on accessing the administration of justice, the annual cost of these justice issues varies from $0.5 \%$ to $3 \%$ of GDP in most countries. In addition to these daily legal needs, underestimated or marginalized communities such as women or minorities also face structural injustices (these injustices could manifest themselves as a takeover by market price of land from an ethnic or indigenous group, the destruction of the environment from proximity to a poor community or violation of rights by government institutions or corporations). In its 2019 report, Justice for All, the Justice Task Force, details and compares justice issues and supports structural reforms to better ensure access to justice (Council of Europe, 2013).

Barriers to access to justice for people living in poverty are an unresolved issue in all human societies. The lack of resources to ensure subsistence has a major effect on the difficulty of understanding the social, economic and legal context in which those people live. Traditional barriers to ensuring a normal diet, as well as barriers to accessing basic services for the vulnerable population - education, health, housing and employment have a decisive impact on the ability of these people to access the justice system. Thus, it is estimated that many other factors prevent poor people from accessing justice (Njupouen, Bolivar René, 2005):

- Access to legal information, the rule of law, distrust of the law

- Reluctance to resort to law enforcement

- Education, legal literacy

- Inadequate legal representation

- Justice is delayed

Problems with the justice system often occur or follow one another and are usually associated with wider social, health or economic problems. The impact of problems with the justice system can cause and / or aggravate wider social problems, including poverty. The figure below illustrates an example of a vicious cycle of poverty involving problems with the justice system, and the grouping of problems is also generated when some types of problems arise from sets of similar circumstances or are associated with the same demographic factors.

Figure 1. The vicious cycle involving justified and extensive socio-economic problems.

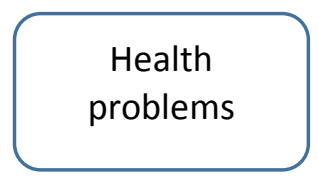




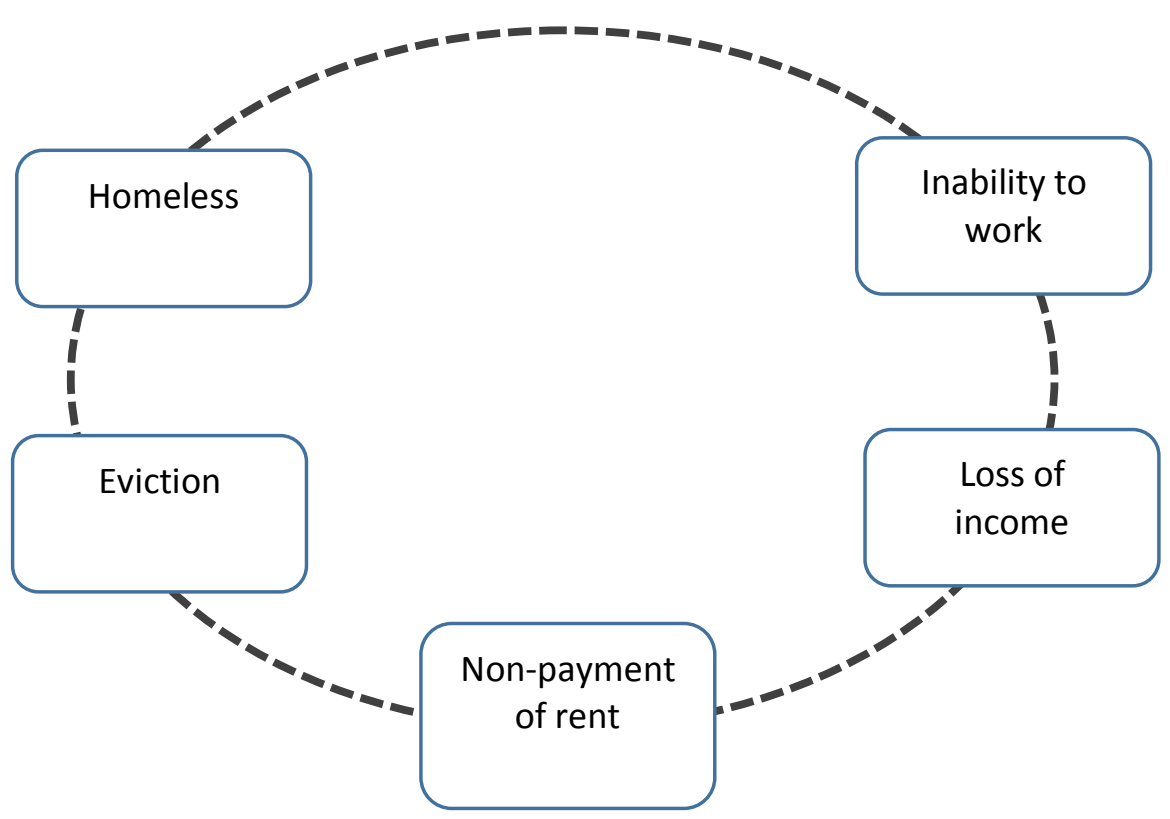

Source: Tobin Tyler et al. (2011).

The vicious circle of precarious situation among Roma people through which poverty is described as an important factor of low school participation along with the recognition of cultural models specific to different types of Roma communities (Dobrică, Jderu, 2005) brings to the fore the extensive and diversified needs of vulnerable groups. It is obvious that Roma people are victims of the vicious circle of poverty (Nicolaescu, 2016, p.73), and efforts to correct systemic problems refer to approaches specific to "bottom-up" inclusion (Cace, 2018a; Cace, 2018b; Cace, 2019; Cace, Sfetcu, Koutmalasou, Nicolaescu, 2012), focusing on interventions specific to education and employment (Cace,, 2018; Nicolaescu, Cace, Dimitris, 2012) or ensuring an optimal level of financing the social inclusion of vulnerable groups through social entrepreneurship (Nicolaescu, Cace, Koutmalasou, Priestess, 2011; Cace, Nicolaescu, Katsikaris, Parcharidis, 2012).

A difficulty reported in the intersection with other analyzes refers to the inclusion of aspects of vulnerability at the level of ethnic group deeply affected by socio-economic problems, such as the case of Roma ethnics. The report "Analysis and evaluation of vulnerable groups in order to establish the need for social services" (developed within the project "Implementation of a system for developing public policies in the field of social inclusion at the level of MMJS", POCA 2014-2020, p. 15 -16) identifies the following as main vulnerable groups: the elderly, people at risk of poverty, children in the family, children separated or at risk of separation from parents, young people in difficulty, adults with disabilities, mother and child. Although Roma people are not 
specifically indicated as a vulnerable group, the same report highlights the fact that at the national level as among the main social issues mentioned by the representatives of the territorial administrative units, the Roma minority is also listed.

At national level, the main social problem mentioned by the representatives of the territorial administrative units, in $52.3 \%$ of the localities, is the lack of jobs. The next problem reported is poverty. It covers $17.5 \%$ of the total ATU. These two social issues rank 1 st and 2 nd in importance both nationally and in each region. The lack of care services for the chronically ill, disabled or elderly is on the 3rd place at national level, with a share of $4.4 \%$. The problems of single elderly people, the aging population and the integration of Roma people occupy the 3-5 places with weights between $2 \%$ and $3 \%$. With a cumulative share of $17 \%$, there are other social problems that do not exceed, each, $2 \%$ of the total answers. Some of these problems are, however, with greater weight, at the level of the development region.

Source: Analysis and evaluation of vulnerable groups in order to establish the ne for social services, Project "Implementation of a system of public poli development in the field of social inclusion at the level of $M M J S^{\prime \prime}$, p. 26

In order to identify obstacles and barriers to access to justice for vulnerable groups and, in particular, the Roma, a comprehensive data collection system is needed in order to assess the degree of discrimination of these groups. Also, the lack of accurate figures on the Roma prevents the development of political responses from state authorities regarding their inclusion. According to an opinion poll conducted by the National Council for Combating Discrimination in Romania in 2015, the Roma represent the fourth least accepted group by the population (after people with HIV, drug addicts and people with disabilities). Decision-makers, organizations, national and European institutions in the field of Roma issues recognize that Roma have limited access to quality education, have difficulties in integrating into the labor market and face a higher risk of unemployment and job insecurity. which reduces their chances of reducing poverty and social inclusion through work, leading to low income levels, limited access to quality medical services and poor health and living conditions.

\section{Research methodology}

The hypothesis of the study is that the incidence of legal problems at the level of the studied community is high and that many barriers to a real and effective access of Roma to justice still persist.

The conclusions of the comprehensive study dedicated to Roma access to justice conducted by the Superior Council of Magistracy and published in 2014 were an important reference in formulating research questions and hypotheses in this study: 
- The assessment of equal access to justice is difficult to achieve because there is no or very little data on the persons belonging to these categories who address the courts, the reasons and the results of these proceedings.

- Costs are not at a level accessible to vulnerable groups in general, as well as Roma in particular.

- Judicial information is available in a variety of formats, but it is not adaptable and easily accessible to vulnerable groups.

- Gender and ethnicity do not have a significant impact on ensuring access to justice for vulnerable groups in general, but prejudice still plays a role in this regard.

- The lack of trust among the Roma population in the judiciary is very high and is reflected in its access to justice (the highest level of distrust is manifested in the police and prosecutors and, to a lesser extent, in judges).

- The judiciary has not developed mechanisms to recognize the discrimination faced by vulnerable groups, especially the Roma population (in this sense, only a very small percentage of court respondents consider that Roma face discrimination in various spheres of social life).

- Most of the challenges faced by the Roma population are considered to be the result of lack of identity documents, property disputes and lack of civil registrations / documents.

The three main research questions are directly related to the research objectives:

- What are the legal needs of members of the Roma minority in Prahova and Buzau counties?

- What are the obstacles that the members of the Roma minority from Prahova and Buzău counties face in accessing the justice institutions?

- What actions should be taken to facilitate access to justice for members of the Roma minority?

From the three questions arise several secondary research questions that can be included in the specific analyzes of access to justice regarding Roma people:

- Does the current legal framework ensure / guarantee equal rights and equal access to justice for all, in line with relevant international standards?

- What are the main legal problems faced by members of the Roma minority in Prahova and Buzau counties? What is their nature?

- Which of the legal problems encountered are perceived as the most serious or difficult to solve?

- What are the ways to solve problems? Where do you try to get information, advice or representation? Where do people go to seek justice and gain respect for their rights? 
- What are the main difficulties faced by members of the Roma minority when addressing a judicial institution?

- Do members of the Roma minority receive fair treatment during proceedings before the institutions of justice?

- Do people get a proper solution to problems? Do they manage to get the decisions enforced?

- Does accessing justice institutions to solve problems generate certain negative consequences for members of the Roma minority?

- What is the level of confidence of the members of the Roma minority in the possibility of resolving the legal problems they face through the institutions of justice? Which of these institutions do you trust the most?

- What are the factors that could contribute to increasing access to justice for members of the Roma minority in Prahova and Buzau counties?

The applied research tool was represented by interviews with the Roma target group to identify legal needs and existing obstacles to access to justice, as well as their perception (individual perspectives) on access to justice for persons belonging to the Roma minority. It was also intended to conduct semi-structured interviews for Roma representatives and for representatives of courts / bars / public institutions / local authorities / NGOs, but in the context of the COVID-19 pandemic it was difficult to organize meetings with them in conditions of safety.

The interview was conducted face to face and conducted on the basis of interview guides, with the collection of data on paper, aiming at maintaining the freedom of response of respondents and respecting their views.

The duration of the interviews expected to be approximately 45-60 minutes was exceeded due to the need to clarify the questions and their complexity in relation to the level of knowledge of the respondents. It was also necessary to repeat certain questions in order to verify the understanding of the meaning of the terms and to ensure an optimal level for validating the answers.

The established sample referred to Roma from Prahova and Buzău counties, selected from the target group of the project, in which sense 207 interviews were conducted by 2 research operators in the communities of Buzău county (Buzău, Calvini, Cilibia, Mihăileşti, Cândeşti localities) and Prahova (Ploieşti). Finally, after verifying and validating the answers recorded on paper, 140 interviews were validated, 70 interviewtype questionnaires from each county to ensure a balanced level of representativeness of Roma respondents in Prahova and Buzau counties.

The content of the interview was structured on the basis of a questionnaire containing 23 questions divided into three parts: 
I. Prevalence and severity of legal problems with 3 open-ended questions that refer to the nature of the problems alleged to be encountered by Roma citizens, the number of questions and the severity of the problems.

II. The nature of the problems and strategies for solving them with 11 questions (4-14) The questions in part II of the interview-type questionnaire refer to the problems mentioned by the respondents and identified with difficulty scores.

III. Confidence and perceptions of the justice system with 9 questions (15-23)

The main topics addressed relate to:

- the nature of the legal problem,

- what was requested in the justice system,

- with whom was the legal issue,

- who had more resources to solve the problem,

- if the respondent shared the problem with someone else,

- if he thought that the problem was due to the fact that he had been discriminated against,

- where he obtained information to solve the problem and how useful that information was,

- from whom he received information, advice, counseling, if they helped him and if he would recommend the type of counselor to others

- if they did not seek help why not

- what problems they encountered when trying to seek help

- what actions he took (respondent or counselor on behalf of the respondent) in order to solve the problem

- how the problem was solved and whether it was correct for all involved

- whether they were discriminated against during the problem-solving process and whether the process was fair to all involved

- payments made by respondents, how difficult it was to get the money needed for expenses, who helped them

- how they would describe the problem and what their conclusions are about the problem, process and solution

The questions in the third part of the interview questionnaire were addressed to the respondents who gave a difficulty score lower than 4 to the mentioned problems or stated that they have no problem. Next, we will present the main conclusions regarding the trust and perceptions of the Roma in Prahova and Buzau on the justice system. 


\section{The results of research on Roma trust and perceptions of the justice system}

Regarding the trust of Roma citizens in the justice system, it can be stated that $33 \%$ of female respondents from rural areas in Buzau and Prahova counties consider that they cannot solve difficult problems even if they try hard enough. The proportion of Roma citizens who do not think they can solve difficult problems even if they try hard is higher than that of rural respondents. The percentage of women in urban areas who believe this is $67 \%$. As for men, $40 \%$ of rural male respondents believe that they cannot always solve difficult problems even if they try hard enough compared to $60 \%$ of urban male respondents.

As expected, the opinion of the respondents that they cannot solve difficult problems even if they try quite a lot varies with the occupation. Thus, $50 \%$ of inactive females in the two counties and $60 \%$ of inactive male respondents consider the statement "I can manage to solve difficult problems if I try hard enough to be completely untrue. Solving difficult problems insistently is the prerogative of young people, but also of life experience, as evidenced by the fact that, in the two counties, young people between 25 and 35 years of age consider $41 \%$ perfectly true the statement that "I can solve problems difficult if I try hard enough ", while $31 \%$ of them consider the statement to be untrue.

A look at Buzau County reveals that out of the total number of respondents, $32.86 \%$ of them, aged between $25-35,52 \%$ consider that they can always manage to solve difficult problems if they try hard enough, while 35\% believe that the statement that they can always solve difficult problems if they try hard enough is not true. Regarding the $35.71 \%$ of respondents, aged $36-54,52 \%$ believe that they can solve difficult problems if they try hard enough and only $8 \%$ of them think it is not true.

At the level of Prahova county, the experience in solving difficult problems has its say, given the fact that the largest share of respondents according to age, respectively $40 \%$ are in the category 36-54 years. 32\% consider that the statement "I can solve difficult problems if I try hard enough", 25\% moderately true and 11\% completely untrue are perfectly true.

Regarding the statement "I can stay calm when I face difficulties because I can rely on my coping skills" - 52\% of female respondents and $61 \%$ of men answered perfectly true. Completely untrue, $9 \%$ of women and $1 \%$ of men interviewed answered. It seems that women are better able than men to stay calm in the face of difficulties, based on their abilities than men. Also, in addition to gender, the environment influences the behavior of respondents in the face of difficulties. Thus, Roma women in rural areas consider that they can remain calm when they face difficulties, based on their skills in proportion of $71 \%$, while women in urban areas are calm in proportion of only $27 \%$. Also, $70 \%$ of Roma men in rural areas believe that they can remain calm when facing difficulties, based on their abilities. The share of men who rely on their abilities to solve the problems they face decreases in urban areas to $41 \%$. 
Regarding the desire to defend their rights, it is found that it exists almost equally in women and men, in rural and urban areas. Thus, $46.27 \%$ of female respondents out of the total respondents point out that they do not avoid defending their rights because they are not sure that I will be successful, while $71.43 \%$ consider that it is not true. Only 38.46\% of the responding Roma women from Buzău and Prahova counties consider that they avoid defending their rights given the fact that they are not sure that they will be successful. Regarding the male Roma respondents from the two counties analyzed from the total number of respondents, $61.54 \%$ consider that they avoid defending their rights given the fact that they are not sure that they will be successful. While $53.73 \%$ of male respondents consider that the statement that they do not defend their rights because they are not sure that they will be successful is completely untrue. $50 \%$ of Roma citizens interviewed $(29.29 \%$ women and $20.71 \%$ men) are not afraid to speak directly to people to defend their rights, they are moderately afraid $22.14 \%$, $10.00 \%$ they are afraid and $14.29 \%$ are a little afraid.

The analysis reveals that the respondents $(19.29 \%)$ who are not afraid to talk directly to people to defend their rights are those between 36 and 54 years old, of which $11.43 \%$ are men and 7,86\% are women. Regarding the environment of origin of the respondents, it is noted that Roma interviewees in urban areas are not afraid to talk directly to people to defend their rights in proportion of $32.69 \%$ compared to $60.23 \%$ in rural areas. In terms of gender, men are not afraid to talk to people $17.31 \%$ in urban areas and $36.36 \%$ in rural areas. While women are not afraid to talk to men to defend their rights in the proportion of $15.38 \%$ in urban areas and $23.86 \%$ in rural areas. At the level of Buzau county, the share of those who are not afraid to speak directly with people to defend their rights is $71.43 \%$, of which $42.86 \%$ are men and $28.57 \%$ are women. The analysis reveals that the respondents from Buzau County who are not afraid to talk directly to people to defend their rights are those between the ages of 25 35 and 36 - 54 (25.71\% for each category in part). It is noted that in Prahova County, those who are not afraid to speak directly with people to defend their rights are those aged 36 to 54 years (12.86\% of which $7.14 \%$ men and $5.71 \%$ women).

The interviewed Roma citizens consider that "they know how to find information to help solve problems" in the proportion of $29.29 \%$, moderately true $-38.57 \%$, untrue $21.43 \%$, completely untrue $7.14 \%$ and do not answer / do not know $-3.57 \%$.

Respondents in urban areas $(13.46 \%)$ in the 36-54 age group consider that it is completely untrue that they know how to find information to help them solve problems. The statement aims that respondents believe that they are good at finding information that could help them solve their problems and not at the existence of sources of information about access to justice. This knowledge may come from attending seminars and presentations about their rights to access to justice, including ways and means of information, but it can also be the result of a high degree of confidence in one's own strength or the strength of others. persons or institutions.

According to the opinions of the rural respondents, in proportion of $29.55 \%$ they know how to find the information necessary to solve the problems, and $44.32 \%$ consider that the statement "I know how to find information to help solve the problems" is moderately true. Contrary to the general opinion that access to information varies with 
the environment, respectively the urban environment being an environment where access to information is easy, there are several sources of information, the analysis reveals that Roma interviewees from rural areas in proportion to $20.45 \%$ say that it is not true that they know how to find information to help them solve problems, and $3.41 \%$ say that this is completely untrue.

Roma respondents from the two counties analyzed are not very confident $(40 \%)$ that they can get correct results in the event of a dispute with an official authority. In contrast, $25 \%$ of respondents feel confident that they can get a fair result from a dispute with an official authority, compared to $22.14 \%$ of those who are not at all confident. From the category of those who do not feel at all confident, $12.86 \%$ are women and only $9.29 \%$ are men. In contrast, of the $40 \%$ of respondents who are not too confident in a correct result in case of a dispute with an official authority, $24.29 \%$ are men and $15.71 \%$ are women. A fairly small percentage of respondents are very confident that they can get a fair result in a dispute with an official authority (5.71\%). A look at these respondents shows that there are female respondents in proportion of $4.29 \%$, of which $2.86 \%$ in the age range $36-54$ years, with high school education $(1.43 \%)$. The share of fairly confident respondents in rural areas is $34 \%$ compared to only $10 \%$ in urban areas.

At the level of Buzău county, the distribution of opinions is somewhat balanced, because $47.14 \%$ of respondents are not too confident that they can get a fair result, with which to be satisfied if they have a dispute with an official authority on, for example, a request heating subsidy, while $41.43 \%$ feel quite confident. At the level of Prahova county, $38.57 \%$ of the respondents consider as "not at all confident" in a correct result with which to be satisfied if they had a dispute with an official authority, of which $21.43 \%$ are women and $17.14 \%$ are men. "Not too confident" represents $32.86 \%$ of those interviewed, of which $14.29 \%$ women and $18.57 \%$ men. It is noted that, in Prahova County, a relatively small percentage $(10 \%)$ of respondents believe that they can get a fair result, with which they would be satisfied if they had a dispute with an official authority.

No matter how confident or less confident the respondents are that they could resolve a dispute with a public authority correctly, if they did not resolve the dispute on their own, then they would turn to the police, court, court, other state institutions, lawyer, court, town hall, family, friends and acquaintances. It is noted that for $19.29 \%$ of all respondents the mayor's office is the place where they can find specialized help to resolve any disputes with official authorities. In the preferences of the respondents from the two counties follow the lawyer $(11.43 \%)$, the police $(7.15 \%)$, the local expert $(5 \%)$ and the social assistance $(4.29 \%)$. With percentages around $2 \%$ the respondents seek specialized help from family, friends, acquaintances, lawyers, institutions competent in solving the problem. At the level of Buzău county for $37.14 \%$ of the respondents the place where you can find and request specialized help is the mayor's office, while in the top of the preferences of Roma respondents from Prahova county as a place where they can find specialized help is the lawyer $-12.86 \%$.

In Buzău county, the share of those who are not too confident in obtaining a correct result, in case of a dispute with an employer is $65.71 \%$, and in Prahova county $32.86 \%$. 
The degree of distrust of the respondents in obtaining a correct result in case of a dispute with an employer is higher in Prahova (41.43\%) than in Buzău County $(21.43 \%)$. If he could not properly resolve a dispute with a single employer, then the respondent would call the police, lawyer, city hall, AJOFM, CNCD, ITM, court, labor protection to receive help. It is noted that for $26.43 \%$ of the total respondents the lawyer is the person where they can find specialized help to resolve possible disputes with employers. In the preferences of the respondents from the two counties, the police follows with $21.43 \%$.

Regarding the trust of the respondents regarding the way of solving a situation of domestic violence, at the level of the two counties subject to analysis, $20 \%$ are very confident, $27.14 \%$ are quite confident. While not too confident are $30 \%$ and not at all confident $19.29 \% .17 .86 \%$ of male respondents are quite confident that they can get a fair result to be satisfied in a situation of domestic violence, while $15 \%$ are not very confident. In Buzau County, respondents are not too confident in getting a fair result in a situation of domestic violence $(34.29 \%$ ), while $31.43 \%$ are quite confident and $25.71 \%$ are not at all confident. The trend at the level of the two counties is also found at the level of Buzău county, women being in a large proportion $(18.57 \%)$ distrustful in obtaining a correct result in case of domestic violence, while men are in proportion of $22.86 \%$ quite confident. At the level of Prahova county, 35.71\% of the respondents are very confident in terms of obtaining a correct result in case of a situation of domestic violence, quite confident $22.86 \%$, and not very confident $25.71 \% .12 .86 \%$ of men are quite confident and $15.71 \%$ are very confident. If they could not properly resolve a situation of domestic violence, then the respondent would first turn to the police $(40 \%)$, lawyer $(15.71 \%)$, family $(7.86 \%)$, police / court $(5 \%)$.

The respondents from Buzău county go mainly to the police in proportion of $37.14 \%$, lawyer $-28.57 \%$, police / judges $-11.43 \%$, court $-10 \%$. Women mainly turn to a lawyer $(15.71 \%)$, police $(11.43 \%)$, police / court $(8.57 \%)$. At the level of Prahova county, the respondents go mainly to the family $(15.71 \%)$ in order to obtain a correct result in a situation of domestic violence, police $(42.86 \%)$, lawyer $(2.86 \%)$. It is found that Roma women are willing in proportion of $25.71 \%$ to the police compared to male respondents of $17.14 \%$ Roma.

It is noted that $72.14 \%$ of respondents in the two counties do not know or do not know places where they can receive free legal advice if they need it. Thus, $36.43 \%$ of male respondents and $35.71 \%$ of female respondents stated that they do not know or do not know where they could get specialized legal advice.

At the level of Buzău county, it seems that $67.14 \%$ of the respondents do not know the places where they can receive free consultancy, of which $40 \%$ are men and $27.14 \%$ are women. Respondents from Prahova County know where they could get free advice $17.15 \%$.

It is worth noting that women consider to a greater extent than men that the Roma Party is the place where they can get free legal advice. Instead, the ombudsman is known as a place where you can get free legal advice to the same extent by both women and men interviewed in Prahova County. 
Opinions are divided on the fact that issues related to disputes with official authorities, employers or issues related to domestic violence are usually resolved promptly and effectively. The share of respondents who mainly disagree and who do not agree at all represents more than half of those interviewed. Male respondents agree more with this statement than women. At the level of Buzau county over half of the respondents agree that such problems are solved promptly and efficiently $(28.57 \%$ agree and $27.14 \%$ mainly agree), while $25.17 \%$ mainly do not they agree, and $17.14 \%$ do not agree at all with the fact that the problems are solved promptly and efficiently. Respondents from Prahova County agree that the problems they have are usually solved promptly and efficiently in proportion of $31.43 \%$ (12.86\% women and $18.57 \%$ men), $4.29 \%$ are mainly agree $(1.43 \%$ men and $2.86 \%$ women).

At the level of Buzău county, 90\% of those interviewed agree that "People with less money generally get a worse result", of which $38.57 \%$ are women and $51.43 \%$ are men. Obviously, the opinion of the interviewees varies directly with the financial resources of the respondents: $50 \%$ of the respondents who agree with this statement have incomes below 1000 lei. In Prahova County, the percentage of respondents who agree with the statement that "People with less money generally get a worse result" $(81.43 \%)$ is lower than in Buzau County (90\%). Of the $81.43 \%$ of respondents who agree that people with less money generally get a worse result are rather women $(47.14 \%)$, of which $21.43 \%$ have incomes below 1000 lei , 11.43\% have incomes between 1000 lei and 2000 lei, than men $(34.29 \%)$, distributed almost equally in terms of income: $11.43 \%$ with incomes below 1000 lei, 10\% with incomes between 1000 lei and 2000 lei and $11.43 \%$ without income.

A percentage of $74.29 \%$ of the total respondents from the two analyzed counties (36.43\% women and $37.86 \%$ men) agree that the Roma rarely get what they want when they go to court. Of these, $27.86 \%$ are in the age category $36-54$ years $(13.57 \%$ women and $14.29 \%$ men), $20.71 \%$ are in the category $25-35$ years $(9.29 \%$ women and $11.43 \%$ men), $15 \%$ are in the category 55 years and over (7.86\% women and $7.14 \%$ men) and $10.71 \%$ are in the category under 25 years $(5.71 \%$ women and $5 \%$ men).

In Buzau County, $70 \%$ of respondents agree that Roma rarely get what they want in court (30\% women and $40 \mathrm{men}$ ), and their largest share $25.71 \%$ fall into the age group $36-54$ years (10\% women and $15.71 \%$ men), $21.43 \%$ are in the age group $25-35$ years $(8.57 \%$ women and $12.86 \%$ men), and $14.29 \%$ are in the age group age 55 and over evenly distributed by gender $(7.14 \%)$.

Of those interviewed, $74.29 \%$ believe that Roma rarely get what they want when they go to court, and $72.14 \%$ (40.71\% women and $31.43 \%$ men) of respondents believe that bringing a case to court it causes more problems and is not worth the effort. This category mainly includes those who graduated high school $(12.86 \%)$, gymnasium $(15.71 \%)$, college $(5 \%), 10$ classes $(5 \%)$ and even without education $(12.86 \%)$. However, there are also $12.86 \%$ of respondents (4.29\% women and $8.57 \%$ men) who mainly disagree with the statement "Taking a case to court generally causes more problems than it deserves". These are the ones who went to court both women and men and had satisfactory results, regardless of age, education, income, marital status or environment. 
At the level of Buzău county, the percentage of those who believe that bringing a case to court causes more problems is $65.71 \%$ of which $35.71 \%$ women and $30 \%$ men, lower than the two counties as a whole. In contrast, in Prahova County, the percentage of those who believe that bringing a case to court causes more problems than it deserves increases to $78.57 \%$, of which $45.71 \%$ are women and $32.86 \%$ are men.

Respondents stated that in order to resolve issues such as disputes with official authorities, employers or in cases of domestic violence, they would use a lawyer, but $91.43 \%$ consider that lawyers are too expensive for most people to use their services, of which $45 \%$ women and $46.43 \%$ men. Although the vast majority of respondents believe that the services of lawyers are too expensive to use in case of problems, still $24.29 \%$ of respondents agree with the statement "For problems like these, people like me can afford the help of a lawyer", without their income influencing their opinion.

\section{Conclusions}

There are currently a variety of economic, structural and institutional factors that impede access to justice, including the complexity and cost of legal processes, time and geographical and physical constraints. Beyond the structural, systemic and individual issues analyzed in various studies on access to justice, many people - especially those in vulnerable and marginalized groups - do not recognize their problems as legal and do not identify possible legal remedies for these problems. Lately, costs, including the opportunity cost and trust in the justice system, have been particularly addressed as important factors in determining whether or not people seek legal aid or taking steps to resolve their legal issues (OECD, Open Society Foundations, 2016).

Access to justice generally refers to the implementation of the rights that the citizens of a state expect to be respected and exercised equally, regardless of nationality, race, sex, religion, sexual orientation, etc. In other words, access to justice reflects the extent to which a state is concerned with the ability of people to obtain a just solution to justified problems and to enforce their rights in accordance with human rights standards (UNDP, 2005, p.5). Access to justice also denotes the extent to which citizens are able to gain access to the legal services needed to protect and claim their legal rights. In functional terms, this does not mean that the use of legal services is only necessary to ensure access to justice, but to provide adequate services for those who are not able to obtain adequate solutions to the problems of vulnerability they face.

In order to ensure that the justice system is accessible to all justice seekers leading to the full realization of their rights, it is important to identify and know the barriers faced by Roma citizens when pursuing the observance of a right provided by law. We must also agree that lack of access to justice limits the effectiveness of poverty reduction and democratic governance programs, undermining participation, transparency and accountability. Mobilizing for the observance and guarantee of fundamental rights, civil and social rights that can be assimilated as alternative actions to access to court (such as marches, peaceful protests, media and political mobilization) can indeed lead to positive results, but at the same time they can erode public confidence and trust in the justice system. The trust of Roma people in the system that guarantees their fundamental 
44 Acces to justice - Trust and perceptions of the roma minority

rights is directly reflected in the justice systems that have the obligation to continuously address and improve access to justice.

\section{Funding}

The author received no financial support for the research, authorship, and/or publication of this article.

\section{Declaration of conflicting interests}

The author declares no conflicting interests.

\section{References}

Consiliul Europei (2013). Liniile directoare revizuite privind crearea hărţilor judiciare de susţinere a accesului la justiţie în cadrul unui sistem judiciar de calitate, Adoptate la cea de-a 22-a şedința plenară a CEPEJ din data de 6 decembrie 2013, Grupul De Lucru Privind Calitatea Justiției (Cepej-Gt-Qual)

Consiliul National pentru Combaterea Discriminarii (2015). Perceptii si atitudini ale populației României față de Strategia națională de prevenire si combatere a discriminärii, accessed on https://www.cncd.ro/wp-content/uploads/ 2021/01/Sondaj_TNS_CNCD_2015.pdf.

Consiliul Superior al Magistraturii (2014). Accesul la justiție al grupurilor vulnerabile in România

Cace C., Nicolaescu V., Katsikaris L., Parcharidis I. (2012). Managementul resurselor umane implicate în economia socială. Bucureşti: Editura Expert.

Cace C., Sfetcu L., Koutmalasou E., Nicolaescu V. (2012). Incluziunea femeilor și grupurilor roma excluse social. Bucureşti: Editura Expert.

Cace, C. (2018a). Intervention in Roma communities. Vocational training and employment, Journal of Community Positive Practices, 18(3), 66-113.

Cace, C. (2018b). Intervention in Roma communities. Action on labour market, Journal of Community Positive Practices, 18(4), 57-109

Cace, C. (2019). Intervention in Roma communities. Participation in formation activities, Journal of Community Positive Practices, 19(1), 43-76

Meçe, M. (2015). Accessible Justice System For All: The Case of The Roma Minority in Albania, Ecmi Working Paper \#84

Nicolaescu V., Cace C., Dimitris H. (2012), Finanțarea activităţilor de economie socială. Bucureşti: Editura Expert. 
Nicolaescu V., Cace S., Koutmalasou E., Preoteasa A. M. (2011). Imbunătătirea incluə̃unii sociale prin economie socială. Bucureşti: Editura Expert.

Nicolaescu, V. (2016). Poverty of the Romanian Roma minority - current dimensions, Journal of Community Positive Practices, 16(1), 68-77

Njupouen, B. R. (2005). Access To Justice for The Poor What Role for Bar Associations? The Case of Cameroon by I. A Dissertation submitted in partial fulfilment of the requirement for the award of the Master of Science in Governance and Development Management. University of Birmingham

OECD, Open Society Foundations (2016). Leveraging the SDGSs for Inclusive Growth: Delivering Access to Justice for All.

World Report Justice, (2020). Rule of Law Index. Washington 